\title{
WYBRANE ASPEKTY PROBLEMATYKI ZAKAŻENIA WIRUSA HIV I CHOROBY AIDS, A MLODZIEŻ JAKO GRUPA SZCZEGÓLNEGO RYZYKA
}

\section{SOME ASPECTS OF HIV AND AIDS ISSUES}

\section{Streszczenie}

Artykuł dotyczy wybranych aspektów problematyki zakażenia wirusa HIV i choroby AIDS w odniesieniu do młodzieży jako grupy szczególnego ryzyka. Zawarte są w nim dane statystyczne odnośnie omawianego zagadnienia i ewolucja omawianego zjawiska na przestrzeni lat. Zostały ukazane przyczyny wirusa HIV i AIDS, a także potrzeba działań profilaktycznych, informacyjnych i edukacyjnych na szeroką skalę. Zwrócono uwagę na duże znaczenie Krajowego Programu Zapobiegania Zakażeniom HIV, Opieki na Zarażonymi z HIV i Chorymi na AIDS oraz na potrzebę specjalistycznych, długofalowych programów w celu zmniejszenia omawianego zjawiska i zwiększenia świadomości opinii publicznej w zakresie znaczenia i wagi problemów związanych z powyższymi zagadnieniami.

Słowa kluczowe: młodzież, drogi zakażenia HIV, AIDS, leczenia, edukacja, profilaktyka.

\section{Summary}

The article is regarding selected aspects of issues of poisoning the HIV virus and illness AIDS with reference to young people as the group of the 
particular risk. Statistical data are included in it in relation to the discussed issue and the evolution of the discussed occurrence in the course of years. Portrayed causes of the HIV virus and AIDS, as well as the need of preventive, information and educational action stayed for the wide scale.

They paid attention to the great significance of the national programme of preventing Infection with the HIV, Cares on infected with the HIV and sick persons to AIDS and to the need of specialist, long-term programs to the purpose of reducing of the discussed occurrence and increase awarenessing the public opinion in meaning and the importance of connected problems with above issues.

Key words: youth, treatment, education, prevention

\section{WPROWADZENIE}

Choroby przenoszone droga płciową od zawsze stanowiły poważny problem nie tylko medyczny ale też społeczny, psychologiczny oraz moralno-etyczny. Związane jest to z tym, iż choroba weneryczna nie dotyczy wyłącznie samego pacjenta, ale rzutuje mocno na jego stosunki interpersonalne z innymi ludźmi (przede wszystkim w rodzinie, środowisku pracy, w życiu towarzyskim).

W przypadku AIDS ta sytuacja jest szczególnie aktualna, gdyż najgroźniejszym skutkiem tej choroby jest śmierć, a informacje o zakażonym człowieku powodują jego izolację społeczną, stygmatyzację, a nawet marginalizację.

Stąd sytuacja życiowa ludzi zakażonych HIV i chorych na AIDS mieści się nie tylko w problematyce medycznej, ale też i społeczno-pedagogicznej.

\section{SKALA ZAGROŻEŃ}

Szacuje się że na świecie żyje około 39,5mln osób zakażonych HIV i chorych na AIDS. Najwięcej odnotowań jest w Afryce-4,3 mln, następ- 
nie Ameryka Północna i Południowa ponad $3 \mathrm{mln}$. Dynamiczny wzrost zakażeń około $15 \%$ rokrocznie zaznacza się w południowo-wschodniej Azji. W Europie wschodniej i Azji centralnej od 2004 roku ilość nowych przypadków HIV wzrasta rokrocznie około 50\%. Epidemia w Europie ma bardzo zróżnicowane oblicze; Skandynawia i Europa środkowa, w tym także Polska pozostają obszarem o niskiej dynamice epidemii HIV i AIDS. Na zachodzie Europy w sposób szczególny dotknięte zachorowaniem zostały takie państwa jak Wielka Brytania i Niemcy ${ }^{1}$.

W Polsce pierwsze zakażenia HIV wykryto w 1985 r. Badania z roku 1988 ujawniły wielu nosicieli wśród narkomanów. W początkowych latach główną drogę rozprzestrzeniania się zakażeń HIV w Polsce stanowiło stosowanie środków psychoaktywnych w iniekcjach oraz męskie kontakty homoseksualne ${ }^{2}$.

AIDS jest chorobą zakaźną wywołaną przez wirusa HIV (Human Immunodeficiency Virus - ludzki wirus upośledzenia odporności). Zdaniem Cz. Cekiery „HIV należy do retrowirusów, ich szczególną cechą jest posiadanie specjalnego enzymu, który umożliwia w zakażonej komórce przekazywanie informacji genetycznej w kierunku od RNA do DNA. Retrowirusy mają właściwości wnikania do limfocytów o symbolu $\mathrm{T}$ (od słowa chymus - grasica), są to więc limfocyty zależne od grasicy. HTLV-I i HALV-II powodują rozmnażanie się tych limfocytów i prowadzą do rozwoju pewnych nowotworów układu chłonnego"3.

Wyżej wymieniony Autor twierdzi, że dotychczas nie ma całkowitej pewności, skąd się ta choroba wzięła. Pewne poszlaki wskazują na Afrykę jako pierwotne źródło wirusa HIV, który mógł być przeniesiony do Stanów Zjednoczonych, a także do innych krajów Europy. ${ }^{4}$

Wirus ten przekracza swobodnie wszystkie granice rasowe, państwowe, polityczne i ekonomiczne, narodowościowe a także moralne.

\footnotetext{
${ }^{1}$ K. Gajewska, M. Mintało, Sytuacja epidemiologiczna HIV/AIDS na koniec 2006 r. WWW. AIDS.gov.pl zdnia 20. 07. 2011

2 Tamże.

3 Cz. Cekiera, Psychoprofilaktyka uzależnień oraz terapia i resocjalizacja osób uzależnionych. KUL 1998, s. 243.

4 Tamże s. 240.
} 
Zakażenie może nastapić poprzez trzy drogi;

- droga płciowa - najczęstszym sposobem przenoszenia HIV jest około $90 \%$ stosunek seksualny z osobą zakażona;

- droga pozajelitowa - zakażenie może nastapić przez przetoczenie zakażonej krwi lub preparatów krwiopochodnych, przeszczepy, sztuczne zapłodnienie oraz przez używanie zakażonych igieł i strzykawek. W Polsce odsetek zakażonych przez krew i jej produkty, a także przeszczepy lub sztuczne zapłodnienie jest niski i wynosi mniej niż $1 \%$.

- droga wertykalna - istnieją następujące drogi matka-płód gdyż nie ma bariery łożyskowej, w czasie porodu oraz w okresie poporodowym podczas karmienia. ${ }^{5}$

W tzw. naturalnej historii rozwoju AIDS można wyróżnić trzy etapy:

- etap bezobjawowy,

- etap objawów wstępnych,

- pełnoobjawowy zespół chorobowy typowy dla AIDS. ${ }^{6}$

Jak twierdzą Autorzy S. Majewski, I. Rudnicka na każdym etapie zakażenia HIV i AIDS występują różnorodne zmiany na skórze i błonach śluzowych. Ich znajomość pozwala na podejrzenie zakażenia oraz podjęcie odpowiedniego postępowania diagnostycznego. ${ }^{7}$

Początek zakażenia HIV jest bezobjawowy lub objawy nie są charakterystyczne. Najczęściej po 4-tygodniach pojawiają się objawy ostrej infekcji HIV zwanej też chorobą retrowirusową i nie są związane z zakażeniem HIV. Są to najczęściej: powiększone węzły chłonne w obrębie szyi, pod pachami oraz w pachwinach, utrata apetytu i spadek wagi ciała, podwyższona temperatura utrzymująca się dłużej niż tydzień i inne tzw. grypopodobne symptomy. Stwarza to podwójne niebezpieczeństwo ponieważ chory zazwyczaj nie zdaje sobie sprawy z tego, że jest zakażo-

5 B. Daniluk-Kukla, A. Gładysz, Ocena wiedzy i postaw młodzieży szkół podstawowych na temat zakażenia i zapobiegania HIV i AIDS, Poznań 1998, s. 12-13.

${ }^{6}$ A. Skotnicki, Nauka dla wszystkich, AIDS nabyty zespół zaniku odporności. Wroclaw 1986, s. 22.

${ }^{7}$ S. Majewski, I. Rudnicka, Choroby skóry i błon śluzowych w przebiegu zakażenia HIV i AIDS, Poznań 2001 s. 12. 
ny. Objawy utrzymują się 1-2 tygodnie, rzadko się zdarza aby powyższe objawy utrzymywały się dłużej. Od chwili zakażenia po 2-6 miesiącach można wykryć przeciwciała anty-HIV. Ten wczesny okres wykrycia może przynieść najwięcej korzyści w terapii, gdyż liczba zarażonych komórek jest jeszcze mała.

Po wczesnej reakcji organizmu na zakażenie, przychodzi okres bezobjawowy, czyli stadium tzw. utajonego nosicielstwa. Osoba zakażona ma normalne samopoczucie, wygląda i czuje się dobrze. Po upływie kilku lat, rzadko kilkudziesięciu, obniża się odporność organizmu i występuje pełny obraz chorobowy. ${ }^{8}$

Pełno objawowa choroba AIDS, czyli ostatnie stadium infekcji HIV ma dość gwałtowny rozwój, gdyż system odpornościowy jest już tak zniszczony przez wirusa, że organizm pozostaje całkowicie bezbronny przed atakami różnych chorób.

Do typowych objawów towarzyszących AIDS należy zaliczyć: zapalenie płuc, gruźlica, opryszczka, półpasiec, mięsak Kaposiego (złośliwy nowotwór), zespół otępienny, ponadto duszności, ciężkie biegunki, nudności, bóle głowy, zaburzenia pamięci i uwagi, gwałtowne wahania nastroju, spadek masy ciała aż do ogólnoustrojowego wyniszczenia. ${ }^{9}$ Najgroźniejszym skutkiem biofizycznym tej choroby jak wiadomo jest śmierć.

\section{SKUTKI ZARAŻENIA WIRUSEM HIV}

W związku z tym w literaturze naukowej bardzo dużo uwagi zwraca się na skutki medyczne HIV/AIDS. Natomiast o skutkach społecznopedagogicznych, psychologicznych czy moralno-etycznych zakażenia HIV i choroby AIDS pisze się wciąż za mało. Nie mniej jednak okoliczności prywatnego życia osoby zakażonej są często tak skomplikowane, trudne, a nawet tragiczne, że zasługują na osobne zarówno teoretyczne poszukiwania, jak i badania empiryczne. Chodzi o trudne relacje inter-

\footnotetext{
${ }^{8}$ M. Brodman, M. Thaker, R. Kranz, Mity o bezpiecznym seksie a AIDS, Warszawa 1999, s. 86.

9 Tamże s. 88.
} 
personalne człowieka z płcia przeciwną (z dziewczyna, chłopakiem, narzeczona, narzeczonym, młodą żona, młodym mężem), w sytuacji ujawnienia się choroby wenerycznej. Po potwierdzeniu tej groźnej diagnozy stosunki te w zdecydowanej większości przypadków ulegają zaburzeniu i zerwaniu, a perspektywa szczęśliwego życia małżeńskiego leży w gruzach.

W aktualnej dobie w medycynie nie są znane metody wyleczenia zarażenia HIV. Najpopularniejszą stosowaną dziś metodą leczenia jest intensywna terapia antyretrowirusowa (HAART) charakteryzująca się tym, iż pacjentowi podaje się kilka różnorodnych leków mających zaatakować wirusa na różnych etapach jego rozwoju. Efektem terapii nie jest całkowite zniszczenie wirusa w organizmie człowieka, lecz sprowadzenie liczby jego cząstek we krwi do bardzo niskiego poziomu. Sytuacja taka umożliwia odbudowę układu odpornościowego człowieka.

Zdaniem J.Reisman, E. Eichel, „mówienie o tym, że wkrótce pojawi się lek przeciw AIDS jest czystą fantazją. Wirus HIV wbudowuje swój materiał genetyczny do materiału genetycznego komórki nosiciela. Taka komórka staje się potencjalnym źródłem AIDS. Możliwość dokonania czynności wytnij-wklej wewnątrz ludzkiego chromosomu albo zablokowania reprodukcji wirusa w zainfekowanych komórkach nie wydaje się być osiagalna w jakiejś niedalekiej przyszłości." 10

Jedyną szczepionką przeciw AIDS jest obecnie wiedza, która potrafi uchronić osoby dojrzałe, jak również zapobiec nowym zakażeniom wśród młodych ludzi dorastających w dobie AIDS. Dlatego też tak istotne jest skupienie największej uwagi na młodzież albowiem od stopnia przygotowania i wiedzy mogą zależeć jej losy. ${ }^{11}$

Według Autorek J. Szymańskiej, B. Woynarowskiej istnieje potrzeba takich działań informacyjnych i wychowawczych, które byłyby ściśle nastawione na zapobieganie AIDS wśród młodzieży, a jednocześnie do-

\footnotetext{
10 J. Reisman, E. Eichel, Seks i oszustwo. Rzecz o indoktrynacji, Warszawa 2002, s. 202.

11 B. Daniluk-Kula, A. Gładysz, Ocena wiedzy i postaw młodzieży szkół podstawowych na temat zakażenia i zapobiegania HIV i AIDS, Poznań 1998, s. 15.
} 
stosowane do obecnego poziomu jej wiedzy i emocjonalnego zaangażowania $\mathrm{w}$ ten problem. ${ }^{12}$

\section{W KRĘGU PROFILAKTYKI}

Młodzi ludzie potrzebują informacji, aby móc obronić się przed zakażeniem HIV i innymi chorobami przenoszonymi droga płciowa, jednak wiele $\mathrm{z}$ nich pozostaje bez niej i nie wie w jaki sposób można się zarazić, jak również nie potrafi określić własnego ryzyka zakażenia. Wirus HIV przenoszony jest głównie drogą płciową, a wielu adolescentów uprawia seks. Ponadto ryzyko zakażenia zwiększają narkotyki, stosunki homoseksualne, prostytucja, duża liczba partnerów. ${ }^{13}$

Szybko rozwijający się w świecie AIDS stawia wszystkich przed podwójnym wyzwaniem mianowicie zapobieganiem chorobie i opieką nad chorymi. Prawdziwie skuteczne działanie w obu tych kierunkach możliwe jest dopiero wtedy, gdy wspólny wysiłek zostanie skoncentrowany na konsekwentnym nauczaniu i kształceniu dzieci i młodzieży jak zapobiegać HIV, opartych na wszechstronnej opiece pełnej godności wobec osób żyjących z HIV.

Istnieje zatem potrzeba działań profilaktycznych i wychowawczych, które byłyby ściśle nastawione na zapobieganie AIDS wśród młodzieży oraz dostosowane do aktualnego poziomu jej wiedzy i emocjonalnego zaangażowania $\mathrm{w}$ ten problem.

Wiek dorastania jest tym okresem w życiu człowieka, w którym na przestrzeni stosunkowo krótkiego czasu zachodzą radykalne zmiany fizyczne i psychiczne. Umożliwiają one spełnienie zadań właściwych człowiekowi dorosłemu, pełnienie różnych ról społecznych dotyczących rodziny, szkoły, środowiska pracy. Proces dorastania jest niezwykle skomplikowany, obejmuje wiele wymiarów osobowości, przy czym linie rozwoju w tych dziedzinach nie przebiegają równolegle. Poza doj-

12 J. Szymańska, B. Woynarowska i inni, Poziom wiedzy i postawy młodzieży szkolnej wobec HIV/AIDS w Polsce Problemy Rodziny nr 2 1992, s. 35.

13 L. Madras, Porozmawiajmy o AID poradnik dla młodzieży, rodziców i nauczycieli, Warszawa1997, s. 25. 
rzewaniem fizjologicznym, którego końcowym etapem jest możliwość prokreacji, wiele miejsca w rozwoju osoby zajmuje proces realizacji zadań społecznych. Następuje też ogromny postęp zarówno w ilościowym wzroście funkcji umysłowych jak i w jakościowym skoku, w zakresie procesów myślenia, polegającego na przejściu od etapu myślenia konkretnego do myślenia hipotetyczno-edukacyjnego. ${ }^{14}$

Dzięki temu możliwa jest większa efektywność uczenia się i zdolność rozwiązywania problemów, a rozumienie związków między zachodzącymi zjawiskami prowadzi do coraz lepszej orientacji w otaczającej rzeczywistości.

Ważnym aspektem rozwoju młodego człowieka jest również dojrzewanie emocjonalne. Pobudliwość i niedojrzałość emocjonalna ustępuje stopniowo stałości i równowadze. Zwiększa się skala przeżyć emocjonalnych, wzbogaca treść uczuć, wzmaga się rozwój uczuć wyższych; moralnych, społecznych, estetycznych ${ }^{15}$.

Ponadto powstaje wtedy wiele problemów, kompleksów w tym okresie i aby odreagować czy zapomnieć o problemach, które się nawarstwiają, narkotyki wydają się być idealnym rozwiązaniem.

M Żebrowska pisze też o dorastaniu kulturowym, co oznacza, że jednostka przekształca się stopniowo z biernego odbiorcy dóbr kulturowych w coraz bardziej aktywnego i odpowiedzialnego współtwórcę tych dzieł ${ }^{16}$.

Szybkie tempo przeobrażeń i często ich radykalny charakter wywołuje u młodzieży trudności w przystosowaniu się do nowych sytuacji, a także nowych zadań, natomiast od ludzi dorosłych wymaga dużej plastyczności w postępowaniu z młodzieżą.

Podobnego zdania jest K. Ostaszewski, który zwraca uwagę na niektóre prawidłowości rozwojowe okresu dojrzewania, a mianowicie „procesy gwałtownych przemian biologicznych, psychologicznych i społecznych, jakie zachodzą w okresie adolescencji, czynią młodzież podatną na angażowanie się $\mathrm{w}$ zachowania potencjalnie ryzykowne dla

${ }_{14}$ M. Żebrowska, Psychologia rozwojowa dzieci i młodzieży, Warszawa 1982 s. 97.

15 M. Żebrowska, Psychologia rozwojowa dzieci i młodzieży, Warszawa 1982 s. 98.

16 Tamże s. 85. 
zdrowia. Używanie substancji psychoaktywnych, a także inne zachowania problemowe są często rozpatrywane w kontekście zadań rozwojowych wieku dojrzewania. Do tych zadań zalicza się m.in. kształtowanie własnej tożsamości, uzyskanie autonomii i niezależności od rodziców, rozwijanie kontaktów społecznych, doświadczenie fizycznej dojrzałości seksualnej." 17

Zdaniem A. Car ,adolescencja jest tym etapem w rozwoju człowieka, kiedy przestaje on być zależny od rodziców, jak to się dzieje w dzieciństwie, a zyskuje samodzielność. W tym czasie dochodzi do istotnych zmian psychofizycznych, które mają wpływ na seksualność nastolatka. Dorastając człowiek kształtuje w sobie wyraźną tożsamość, czyli poczucie kim jest. Proces ten może w większym lub mniejszym stopniu zwiększyć prawdopodobieństwo zaangażowania się nastolatka w ryzykowne zachowania seksualne. Kształtowanie tożsamości obejmuje cztery fazy:

- tożsamość tymczasowa - jeśli decyzje zawodowe, polityczne bądź religijne są podejmowane w zastępstwie nastolatka przez rodziców lub inne osoby starsze z otoczenia mówimy, że ma on tożsamość tymczasową. Młody człowiek akceptuje te wybory, nie angażując się w podejmowaniu decyzji dotyczących własnej tożsamości. W takich sytuacjach nastolatki mają tendencję do popierania wartości autorytatywnych i istnieje małe prawdopodobieństwo, że podejmą ryzykowne zachowania seksualne,

- rozproszenie tożsamości - nastolatek nie posiada utrwalonych przekonań ani planów osobistych, społecznych, politycznych czy zawodowych. Poszukuje podniecenia i zabawy, przechodzi od sytuacji do sytuacji bez konkretnego długoterminowego planu bądź spójnego obrazu własnej tożsamości. Istnieje wysokie prawdopodobieństwo, że ci którzy bezustannie dążą do podniecenia i zabawy, podejmują także ryzykowne zachowania seksualne,

- moratorium tożsamościowe - dorastająca osoba eksperymentuje z przyjmowaniem wielu ról, zanim uda się jej ukształtować wyraźną

${ }^{17}$ K. Ostaszewski, Skuteczność profilaktyki używania substancji psychoaktywnych, Warszawa 2003 s. 75. 
osobowość. Niektóre z tych ról mogą mieć charakter negatywny bądź niekonwencjonalny. Wyznaczaja jednak kolejne etapy osiagane w trakcie kształtowania stabilnej tożsamości. W okresie moratorium nastolatek może angażować się w ryzykowne zachowania seksualne jako element ról stanowiących przedmiot eksperymentu,

- osiagnięcie tożsamości - u nastolatka po fazie moratorium kształtuje się wyraźnie określona tożsamość, na ogół krystalizują się silne wartości zawodowe, społeczne, polityczne i religijne. Jeśli nastolatek osiagnął poczucie tożsamości w wyniku moratorium, w czasie którego eksperymentował z przyjmowaniem wielu ról, uniknął wielu problemów polegających na braku celu bądź uwikłaniu. Młodzi ludzie którzy wykształcili poczucie tożsamości, są najprawdopodobniej mniej podatni na ryzykowne zachowania seksualne niż ci, którym się to nie udało."18

Rozwój tożsamości młodego człowieka nieodzownie łączy się z kwestią kształtowania określonego podejścia do pełnienia właściwych ról społecznych. To zagadnienie z kolei wiąże się z problemem wartości i wolności osobistej. Jak pisze E. Wolter „, tylko poprzez wolność człowiek może realizować, urzeczywistniać wartość prawdy, dobra, piękna - zarówno w życiu osobistym (rodzinnym), jak i w perspektywie społecznej (ekonomicznej, politycznej, narodowej, międzynarodowej). Podstawą wolności zewnętrznej, zagwarantowanej przez przepisy prawa, jest wolność wewnętrzna - autonomia duchowa każdej jednostki i istoty społecznej, która realizuje się jako Osoba"19

$\mathrm{Z}$ uwagi na powyższe, wiedza jaką powinien posiadać każdy człowiek, a szczególnie młody na temat AIDS, pozwoli zmniejszyć ryzyko zakażenia gdyż problem dotyczy nas wszystkich.

W działaniach edukacyjno-profilaktycznych niebagatelną rolę odgrywają działania następujących instytucji, a mianowicie są to działania: szkoły, kościoła oraz rządowe.

18 A. Car, Program profilaktyki szkolnej w zakresie AIDS i chorób przenoszonych droga płciowa, Gdańsk 2004, s. 9-10.

19 E. Wolter, Wychowanie do równoważenia rozwoju społeczno-przyrodniczego w koncepcji Jana Pawła II (w) Nauczanie Jana Pawła II a współczesna aksjologia pedagogiczna (red) J. Placha, W. Sroczyński. Warszawa 2008, s. 91. 
Szkoła stanowi istotne miejsce w systemie działań profilaktycznych, chociaż pierwszym i najważniejszym miejscem w tego typu działaniach powinna być rodzina. Jednak niezależnie od różnych zmieniających się koncepcji w zakresie zadań społecznych szkoły funkcja profilaktyczna nigdy nie powinna być zmniejszona. Zadaniem jest stworzenie odpowiedniego zintegrowanego z programem profilaktyki, kontekstu wychowawczego, który polega m.in. na promowaniu krytycznego, odpowiedzialnego kontaktu uczniów z otaczającą rzeczywistością. Ponadto jak pisze Z. Gaś „,szkoła jest ważnym miejscem działań profilaktycznych jeszcze $z$ innych względów, pozwala na łatwy dostęp do środowiska dzieci i młodzieży. W szkole uczniowie spędzają znaczną część dnia, realizując różne formy aktywności. Na jej terenie ujawniają się bądź wyzwalają trudności młodych osób związane z funkcjonowaniem w różnych rolach społecznych." ${ }^{20}$ Miejsce działań profilaktycznych wobec HIV przede wszystkim zajmuje realizacja profilaktyki pierwszorzędowej. Działania tego typu mają na celu promocję zdrowego stylu życia i wspieranie rozwoju człowieka, zmianę norm obyczajowych dotyczacych używania środków psychoaktywnych i podejmowania działań ryzykownych. W jej ramach powinny być realizowane postulaty dotyczące kształtowania umiejętności umożliwiających satysfakcję z codziennej egzystencji. W związku z tym należy stwarzać mechanizmy prawne, kulturowe i obyczajowe, które umożliwiają i zachęcą społeczeństwo, a szczególnie dzieci i młodzież do zagospodarowania czasu wolnego oraz czerpania radości z trzeźwego życia. W edukacji szkolnej dzieci i młodzieży należy stwarzać okazję do wyrażania własnych przekonań i opinii, podejmowania samodzielnych decyzji i asertywnych zachowań, które umacniają zaufanie do siebie i pozycję społeczną osoby, a tym samym stanowią podstawę do trzeźwego pokonywania trudności oraz do odpierania presji rówieśniczej. ${ }^{21}$

* Kościół w Polsce i na świecie od zarania swego istnienia swoją posługą obejmuje człowieka, a wszystkie jego egzystencjalne troski

20 Z. Gaś, Profilaktyka w szkole zapobieganie uzależnieniom uczniów 1997 s. 55

${ }^{21}$ B. Kałdon, Profilaktyka alkoholowa w szkole, Stalowa Wola 2003, s. 66-67 
i problemy stanowią źródło oraz inspirację dla oddziaływania kościoła. Jak zauważa A. Nowak „AIDS dla Kościoła stanowi nie tylko problem trudny, ale w swej specyfice szczególnie delikatny. Dotyczy najwyższej wartości, jaką jest życie ludzkie oraz zachowań seksualnych człowieka, wobec których stanowisko etyki chrześcijańskiej dla niektórych osób wydaje się być bardzo wymagające. We współczesnym świecie obserwuje się, że człowiek nie zawsze radzi sobie z wymaganiami etyki chrześcijańskiej w zakresie zachowań seksualnych."22Autentyczna profilaktyka wymaga nakłonienia ludzi do zmiany zachowań seksualnych, które są główną przyczyną rozprzestrzenienia się AIDS. J. Kopciński twierdzi, że tylko moralne odrodzenie może wpłynać na zahamowanie rozwoju AIDS. Papieska Rada do Spraw Rodziny przy różnych okazjach przypomina nauczanie Kościoła w tej kwestii. Jego istotą jest odwoływanie się do ludzkiego i antropologicznego sensu problemu. Również z tą kwestią wiąże się zagadnienie tożsamości mężczyzny i kobiety, a także ich godności, sensu i znaczenia płci. Najbardziej radykalnym działaniem w tej walce, którego skuteczności nikt nie może kwestionować jest wstrzemięźliwość płciowa młodzieży przed małżeństwem oraz czystość małżeńska. Wyżej wymieniony Autor zauważa, że jedyną metodą zapewniającą pełną skuteczność w zapobieganiu zakażeniom HIV drogą płciową jest tzw. absolutna etyka seksualna i oparte na wzajemnej wierności życie małżeńskie. ${ }^{23}$ Kościół wyraża sprzeciw wobec niektórych zachowań, lecz jednocześnie stara się zaproponować styl życia pełen osobowego sensu. Wskazuje ideał pozytywny, w świetle którego należy rozumieć moralne formy postępowania. ${ }^{24}$

* Ministerstwo Zdrowia poprzez Krajowe Centrum ds. AIDS od 1995 roku przygotowało dokument określający politykę państwa w zakresie HIV i AIDS. Powstałe cztery edycje krajowego programu za-

\footnotetext{
${ }^{22}$ A. Nowak, Próba analizy postawy Kościoła Katolickiego do wybranych zagadnień AIDS-Duszpasterskie wyzwanie wobec AIDS i narkomanii, Szczecin 1998, s. 54-55.

23 J. Kopciński, AIDS-Encyklopedia bioetyki. Personalizm chrześcijański. Głos kościoła, Radom 2005 s. 28-29.

${ }^{24}$ W. Gubała, Kościół wobec AIDS. Czy AIDS jest karą za grzechy - Biologia w szkole nr 1 b.r s. 8 .
} 
pobiegania zakażeniom HIV i opieki nad zarażonymi HIV i chorymi na AIDS 1996-1998, 1999-2003,2004-2006 i najnowsza edycja 20072011. Krajowy Program Zapobiegania Zakażeniom HIV, Opieki na Zarażonymi z HIV i Chorymi na AIDS ma charakter strategii narodowej i wytacza dwa cele strategiczne:

- ograniczenie rozprzestrzeniania zakażeń HIV;

- poprawa jakości życia i dostępności opieki medycznej i psychologicznej dla ludzi żyjących z HIV, chorych na AIDS oraz ich bliskich.

Cele główne Krajowego Programu dotyczą trzech podstawowych obszarów problemowych: ograniczenie rozprzestrzeniania zakażeń HIV w Polsce; poprawy jakości życia, dostępności opieki medycznej i psychologicznej dla ludzi zarażonych HIV, chorych na AIDS i ich bliskich; zapewnienie szerokiej dostępności do diagnostyki i leczenie ARV.

Do najważniejszych efektów dotychczasowej realizacji celów Krajowego Programu należą:

1. W płaszczyźnie epidemiologicznej: stabilność sytuacji epidemiologicznej zakażeń; spadek zakażeń drogą wertykalną u dzieci urodzonych przez matki zakażone HIV;

2. W odniesieniu do osób żyjących z HIV, chorych na AIDS: spadek śmiertelności; poprawa jakości życia osób żyjących z HIV;

3. W zakresie profilaktyki HIV: zwiększenie dostępności do anonimowych i bezpłatnych badań w kierunku HIV, gwarantujących wysoką jakość usług w tej dziedzinie; zwiększenie liczby osób testujących się; zwiększenie ilości certyfikowanych edukatorów w dziedzinie HIV i AIDS specjalizujących się w pracy z wybranymi środowiskami tj. szkoły, więzienia; wzrost efektywności prowadzonych kampanii medialnych dotyczących profilaktyki HIV i AIDS. ${ }^{25}$

Krajowy Program podlega stałemu monitorowaniu i ewaluacji, co ma pomóc tak w ocenie, jak i wprowadzaniu ewentualnych korekt wspomagających zwiększenie efektywności podejmowanych działań. ${ }^{26}$

${ }^{25}$ W. Plitta, Edukacja profilaktyką HIV i AIDS, Pracownik socjalny nr 62006 s. 5.

26 Tamże s. 6. 
Harmonogram Krajowego Programu na lata 2007-2011 jest kontynuacją działań realizowanych w ramach założeń trzech poprzednich edycji Krajowego Programu Zapobiegania Zakażeniom HIV; Opieki nad żyjącymi z HIV; Chorymi na AIDS. W programie tym za piorytety uznano następujące kwestie:

1. W zakresie profilaktyki:

- prowadzenie długofalowych programów profilaktyczno-edukacyjnych, ze szczególnym uwzględnieniem młodzieży;

- szkolenia przygotowujące certyfikowanych edukatorów w zakresie rozwiązywania problemów HIV oraz AIDS;

- opracowanie, wydawanie i rozprowadzanie różnorodnych materiałów informacyjno-edukacyjnych;

- systematyczne rozszerzanie sieci punktów konsultacyjno-diagnostycznych prowadzacych anonimowe testowanie w kierunku HIV, z profesjonalnym poradnictwem przed wykonaniem testu i po uzyskaniu jego wyniku;

- współpracę międzynarodową w zakresie wymiany doświadczeń i wdrażania najlepszych praktyk w celu podnoszenia efektywności działań profilaktycznych.

2. W zakresie pomocy i wsparcia dla osób żyjących z HIV i chorych na AIDS oraz ich bliskich:

- promowanie i wspieranie działań organizacji pozarządowych w zakresie zapobiegania zakażenia HIV, pomocy osobom zakażonym HIV i chorym na AIDS;

- wspieranie działań opartych na wolontariacie; promowanie i wspieranie realizacji zadań mających na celu integrację społeczna;

3. w zakresie dostępu do metod diagnostycznych wynikających z aktualnego stanu wiedzy medycznej:

- zapewnienie specjalistycznej diagnostyki monitorującej zakażenie HIV iprowadzoną terapię;

- objęcie dobrowolnymi badaniami w kierunku HIV jak największej liczby osób, ze szczególnym uwzględnieniem kobiet w ciąży.

4. W zakresie leczenia antyretrowirusowego zgodnego $\mathrm{z}$ aktualnym stanem wiedzy medycznej: 
- zapewnienie dostępu do diagnostyki, leczenia oraz jego ciąłości;

- zapewnienie specjalistycznej opieki w okresie ciąży, porodu i połogu nad kobietą zakażoną HIV;

- zapewnienie specjalistycznej opieki dla dzieci zakażonych HIV;

- stałą aktualizację standardów opieki medycznej nad osobami żyjącymi z HIV i chorymi na AIDS w zakresie wprowadzania do terapii nowych leków antyretrowirusowych, zgodnie $\mathrm{z}$ aktualnym stanem wiedzy medycznej;

5. prowadzenie badań, ze szczególnym uwzględnieniem analiz umożliwiających szybką i precyzyjną diagnozę sytuacji epidemiologicznej. ${ }^{27}$

\section{PODSUMOWANIE}

Reasumując warto powiedzieć, iż zadanie profilaktyki zakażenia HIV i AIDS jest szczególnie aktualne w stosunku do młodzieży jako grupy ryzyka. To zadanie spoczywa w dużym stopniu na instytucjach edukacyjnych i opiekuńczo-wychowawczych, w których pracują specjaliści: pedagodzy szkolni, wychowawcy, psychologowie, nauczyciele, a także pracownicy medyczni.

Przechodząc jednak od kwestii ogólnych do zagadnień merytorycznych i metodycznych należy postawić pytanie „Czy i w jakim stopniu kadra pedagogiczna jest obecnie przygotowana do realizacji tego zadania z młodzieżą szkolną”? „Czy dysponuje wystarczającym poziomem umiejętności praktycznych do prowadzenia konkretnych form pracy, np. warsztatów, treningów, grup wsparcia dla uczniów eksperymentujących z narkotykami, prowadzących życie seksualne, mających problemy z prawem."?

Realia praktyki pedagogicznej w szkołach i placówkach opiekuńczowychowawczych obecnie charakteryzują się jednak pewną asymetria. Polega ona na tym, iż w treści pracy profilaktyczno-wychowawczej tradycyjnie zdecydowanie więcej uwagi poświęca się kwestiom dotyczą-

${ }^{27}$ Ministerstwo Zdrowia, Krajowe Centrum ds. AIDS. Harmonogram Realizacji Krajowego Programu Zwalczania AIDS i Zapobiegania Zakażeniom HIV opracowany na lata 2009-2011, Warszawa 2006 s. 6-9. 
cym profilaktyki tytonizmu, alkoholizmu, narkomanii, a problemy dotyczące profilaktyki chorób wenerycznych, w tym HIV/AIDS w wielu placówkach pozostają na marginesie, a czasem i poza nawiasem pracy profilaktyczno-wychowawczej. Wiąże się to m.in. z nieokreślonym czy też wstydliwym podejściem wielu pedagogów szkolnych, nauczycieli, jak i rodziców do poruszania tak delikatnego problemu. Wielu z nich nie bardzo wie w jaki sposób to zadanie można realizować, dlatego przerzuca go na pracowników służby zdrowia, księży i innych. Nie mnie jednak leży ono też w gestii kadry pedagogicznej, zwłaszcza pedagogów i psychologów.

Stąd rozważając nad sposobami efektywności pracy profilaktycznowychowawczej z młodzieżą w szkole i placówkach opiekuńczo-wychowawczych w kontekście zapobiegania HIV/AIDS nasuwają się następujące sugestie.

- W instytucjach pracujących z młodzieżą zachodzi potrzeba opracowania określonej koncepcji systematycznej (a nie dorywczo-okazjonalnej) pracy, ukierunkowanej na profilaktykę chorób wenerycznych, która byłaby wkomponowana w całokształt pracy wychowawczej z młodzieżą szkolną i zajęłaby w niej odpowiednie miejsce;

- Na wyższych studiach pedagogicznych przygotowujących specjalistów do nauczania i wychowania młodzieży w tym pedagogów szkolnych i resocjalizacyjnych należy zwrócić szczególną uwagę na kwestię ich merytorycznego przygotowania do realizacji zadań profilaktycznowychowawczych w omawianym kontekście.

Tylko profesjonalne podejście do realizacji tego trudnego zadania w ścisłej współpracy ze specjalistami z innych dziedzin (służba zdrowia, policja prewencji, kościół) może zapewnić pożądane pozytywne zmiany.

Reasumując można stwierdzić, że niewątpliwie istnieje potrzeba działań profilaktycznych i wychowawczych, które byłyby ściśle nastawione na zapobieganie AIDS wśród młodzieży oraz dostosowane do aktualnego poziomu jej wiedzy i emocjonalnego zaangażowania w ten problem.

Istotną kwestia jest wiedza jaką powinien posiadać każdy człowiek w omawianym temacie, a szczególnie osoby młode, które zwiększaja 
ryzyko zachorowań z uwagi na brak dojrzałości i tym samym błędy, które popełniaja, a zwiększona świadomość co do przyczyn i konsekwencji zachorowań z pewnością pozwoliłaby zmniejszyć ryzyko zakażenia.

W działaniach edukacyjno-profilaktycznych niebagatelną rolę odgrywają działania takich instytucji jak: szkoły, kościoła oraz instytucje rządowe.

Zadanie profilaktyki zakażenia HIV i AIDS jest szczególnie aktualne w stosunku do młodzieży jako grupy ryzyka. To zadanie spoczywa w dużym stopniu na instytucjach edukacyjnych i opiekuńczo-wychowawczych, w których pracują specjaliści: pedagodzy szkolni, wychowawcy, psychologowie, nauczyciele, a także pracownicy medyczni.

Tylko profesjonalne podejście do realizacji tego trudnego zadania w ścisłej współpracy ze specjalistami z innych dziedzin (służba zdrowia, policja prewencji, kościół) może zapewnić pożądane pozytywne zmiany i zmniejszenie omawianego problemu.

\section{BIBLIOGRAFIA}

Brodman, M., Thaker, R. Kranz, Mity o bezpiecznym seksie a AIDS, Warszawa 1999

Car A., Program profilaktyki szkolnej w zakresie AIDS i chorób przenoszonych drogą płciowa, Gdańsk 2004

Cekiera Cz., Psychoprofilaktyka uzależnień oraz terapia i resocjalizacja osób uzależnionych. KUL 1998

Gaś Z., Profilaktyka w szkole zapobieganie uzależnieniom uczniów 1997

Daniluk-Kukla B., Gładysz A., Ocena wiedzy i postaw młodzieży szkół podstawowych na temat zakażenia i zapobiegania HIV i AIDS, Poznań 1998

Gajewska K, Mintało M., Sytuacja epidemiologiczna HIV/AIDS na koniec 2006 r. WWW. AIDS.gov.pl zdnia20. 072011

Gubała W., Kościół wobec AIDS. Czy AIDS jest karą za grzechyBiologia w szkole nr 1 b.r 
Kałdon B., Profilaktyka alkoholowa w szkole, Stalowa Wola 2003

Kopciński J., AIDS - Encyklopedia bioetyki. Personalizm chrześcijański. Głos kościoła, Radom 2005

Nowak A., Próba analizy postawy Kościoła Katolickiego do wybranych zagadnień AIDS - Duszpasterskie wyzwanie wobec AIDS i narkomanii, Szczecin 1998

Majewski S, Rudnicka I., Choroby skóry i błon śluzowych w przebiegu zakażenia HIV i AIDS, Poznań 2001

Madras L., Porozmawiajmy o AID poradnik dla młodzieży, rodziców i nauczycieli, Warszawa1997

Ministerstwo Zdrowia, Krajowe Centrum ds. AIDS. Harmonogram Realizacji Krajowego Programu Zwalczania AIDS i Zapobiegania Zakażeniom HIV opracowany na lata 2009-2011, Warszawa 2006

PlittaW., Edukacja profilaktyką HIV i AIDS, Pracownik socjalny nr 6200

Skotnicki A., Nauka dla wszystkich, AIDS nabyty zespół zaniku odporności. Wrocław 1986

Szymańska J, WoynarowskaB i inni, Poziom wiedzy i postawy młodzieży szkolnej wobec HIV/AIDS w Polsce Problemy Rodziny nr 2 1992

Wolter E, Wychowanie do równoważenia rozwoju społeczno-przyrodniczego w koncepcji Jana Pawła II (w) Nauczanie Jana Pawła II a współczesna aksjologia pedagogiczna(red) J. Placha, W. Sroczyński. Warszawa 2008

Reisman J, Eichel E., Seks i oszustwo. Rzecz o indoktrynacji, Warszawa 2002,

Żebrowska M., Psychologia rozwojowa dzieci i młodzieży, Warszawa 1982 